\title{
CENTRALIZACJA I DEKONCENTRACJA TERYTORIALNA POLICJI
}

Podejmując się rozważań dotyczących centralizacji i decentralizacji administracji publicznej, zasadnym jest dokonanie oceny zorganizowania najliczniejszej służby mundurowej w Polsce, jaką jest Policja, będąca komponentem szeroko rozumianej administracji rządowej. Z ustrojowo-organizacyjnego punktu widzenia administracja rządowa stanowi, obok administracji państwowej i samorządu terytorialnego, jeden $\mathrm{z}$ trzech filarów składających się łącznie na podmiotowy obszar administracji publicznej ${ }^{1}$. Administracja rządowa, w przeciwieństwie do zdecentralizowanego samorządu terytorialnego, występuje w układzie scentralizowanym. Z kolei wśród wielu podmiotów tworzących administrację rządową swoje trwałe miejsce zajmuje Policja, odpowiedzialna w znacznej mierze za stan bezpieczeństwa i porządku publicznego w perspektywie ogólnokrajowej, na szczeblu centralnym oraz w wymiarze lokalnym. Takie przyporządkowanie Policji powoduje, że z założenia przyjąć należy jej zorganizowanie w oparciu o doktrynalną zasadę centralizacji.

Centralizacja (układ scentralizowany) polega na hierarchicznym podporządkowaniu organu lub organów administrujących innemu or-

* Bogdan Jaworski - doktor nauk prawnych, Katedra Prawa Policyjnego, Uniwersytet Rzeszowski.

${ }^{1}$ A. Pakuła, Centralne organy administracji rządowej - rządzenie czy zarządzanie sprawami publicznymi [w:] Nowe problemy badawcze $w$ teorii prawa administracyjnego, red. J. Boć, A. Chajbowicz, Wrocław 2009, s. 397. 
ganowi lub organom administrującym ${ }^{2}$. Innymi słowy, centralizacja zakłada brak samodzielności organów niższego stopnia i ścisłe ich uzależnienie od organów nadrzędnych ${ }^{3}$. Nauka prawa administracyjnego i nauka administracji wypracowały różnorodne definicje centralizacji, opisując to zjawisko w zróżnicowany sposób.

H. Izdebski przez centralizację rozumie proces ograniczania przez władze centralne samodzielności podmiotów korzystających z tego aspektu samorządności oraz rezultat tego procesu, polegający na braku w systemie władz i instytucji publicznej podmiotów, które by nie podlegały osobowo lub służbowo władzom lub instytucjom centralnym ${ }^{4}$. Według M. Chmaja centralizacja może polegać zarówno na takiej organizacji systemu administracji, w którym podejmowanie decyzji należy wyłącznie do organów wyższych, a organy niższe wykonują jedynie czynności przygotowujące do podjęcia decyzji (mówi się wówczas o centralistycznym systemie organizacji administracji), jak i na budowie aparatu w taki sposób, iż rozstrzygnięcia wprawdzie należą do organów niższego szczebla, lecz organy wyższego szczebla mają prawo do wydawania wiążących poleceń i dyspozycji co do określonego załatwienia sprawy. Istotą bowiem centralizacji jest hierarchiczne podporządkowanie i brak samodzielności organów niższego szczebla ${ }^{5}$. Centralizacja administracji może być rozpatrywana z perspektywy dwóch pojęć. „Oznacza strukturę organizacyjną administracji składającą się z kilku stopni organizacji, w której decyzje podejmowane są jedynie przez organ centralny. [...] Oznacza taki skład stosunków wewnętrznych administracji publicznej, w którym część zadań prowadzona jest tylko przez organy państwowe przy rozdziale od administracji samorządowej, np. administrowanie sprawami obrony narodowej czy polityki zagranicznej"6.

2 J. Zimmermann, Prawo administracyjne, Warszawa 2012, s. 134.

3 Prawo administracyjne, red. M. Wierzbowski, Warszawa 2011, s. 92.

${ }^{4} \mathrm{H}$. Izdebski, Ustrój terytorialny Rzeczypospolitej Polskiej i zasada decentralizacji [w:] Ustrój terytorialny państwa a decentralizacja systemu władzy publicznej, red. A. Lutrzykowski, Toruń 2012, s. 15.

${ }^{5}$ Prawo administracyjne. Część ogólna, red. M. Chmaj, Warszawa 2007, s. 90.

6 S. Wrzosek, Kompendium wiedzy administratywisty, Lublin 2008, s. 43. 
B. Sprengel, odnosząc się do badań na temat centralizacji służb policyjnych, podzielił pogląd prezentowany przez J. Malec i D. Malec, według których centralizacja oznacza podporząakowanie organów niższego stopnia organom nadrzędnym oraz skupienie decyzji w organach centralnych ${ }^{7}$. W systemie scentralizowanym organy podporządkowane są pozbawione samodzielności. Organy nadrzędne decydują o sytuacji prawnej pracowników organów niższego szczebla w zakresie ich stosunku pracy oraz posiadają prawo powoływania i odwoływania kierowników tychże organów. Rozstrzygnięcia organu podporządkowanego mogą zostać zmienione przez organ nadrzędny. Organ wyższego stopnia może ingerować $\mathrm{w}$ funkcjonowanie organów niższego stopnia przez polecenia, instrukcje, wytyczne oraz inne akty kierowania ${ }^{8}$. Akty te mają zróżnicowany charakter i przyjmują postać aktów generalnych bądź też indywidualnych. $Z$ całą pewnością centralizacja jest widoczna najbardziej w sferze wewnętrznej, ponieważ występują tu powiązane z nią zazwyczaj akty kierownictwa wewnętrznego9.

J. Niczyporuk utożsamia zjawisko centralizacji generalnie z administracją rządową, wskazując jednocześnie na zróżnicowanie w centralizacji poszczególnych jej działów. Do wyraźnie scentralizowanych zaliczył: administrację skarbową; administrację wojskową; administrację policyjną; administrację służb, inspekcji i straży ${ }^{10}$. W Policji szczególnie dostrzegana jest zależność organów terenowych od decyzji organu centralnego, który kształtuje stosunki pomiędzy poszczególnymi organami oraz wpływa na ich funkcjonowanie. Komendant Główny Policji, pełniąc funkcję organu centralnego, zarządza całą formacją oraz jest przełożonym wszystkich funkcjonariuszy Policji. Zaznaczyć należy również, że pomimo przyporządkowania tej służby pod Ministerstwo Spraw Wewnętrznych i Administracji, minister właściwy do spraw wewnętrznych został obdarzony władztwem jedynie w stosunku do Komendanta Głównego Policji. Oznacza to, że nie posiada

7 B. Sprengel, Decentralizacja policji w Polsce od okresu międzywojennego do III Rzeczypospolitej [w:] Ustrój..., red. A. Lutrzykowski, s. 227.

${ }^{8}$ Administracja publiczna i prawo administracyjne $w$ zarysie, red. M. Karpiuk, J. Kowalski, Warszawa-Poznań 2013, s. 22.

${ }^{9}$ J. Niczyporuk, Dekoncentracja administracji publicznej, Lublin 2006, s. 89.

${ }^{10}$ J. Niczyporuk, Dekoncentracja..., s. 90. 
on uprawnień do wydawania wiążących poleceń bezpośrednio funkcjonariuszom Policji, co w pewnym sensie stanowi o apolitycznym charakterze tej służby.

W organizacji Policji dostrzegalne są elementy dekoncentracji jako nierozłącznego zjawiska procesu centralizacji. Doktryna szeroko opisuje zjawisko dekoncentracji, a poglądy jej przedstawicieli w zasadzie są zgodne. J. Sobczak uważa, że zjawisko dekoncentracji odnosi się do rozproszenia kompetencji, niezależnie od tego, czy organy niższego stopnia mają jakikolwiek zakres niezależności od organów nadrzędnych ${ }^{11}$. Podziela on jednocześnie pogląd prezentowany przez M. Wierzbowskiego i A. Wiktorowską, że rozkładanie kompetencji organu centralnego na organy terenowe stanowi proces dekoncentracji ${ }^{12}$. W dekoncentracji administracji publicznej kładzie się równolegle nacisk na kryterium przekazania kompetencji, ilościowego rozdziału zadań, rozproszenia celów i zmiany ciężkości administrowania $^{13}$.

S. Fundowicz, definiując pojęcie dekoncentracji, dostrzega powiązanie z układem centralizacji, przy możliwości przenoszenia kompetencji. Jego zdaniem dekoncentracja może być rozpatrywana w sensie statycznym lub dynamicznym. W sensie statycznym chodzi o obraz aktualnego rozkładu kompetencji między poszczególne organy aparatu administracji. W znaczeniu dynamicznym chodzi natomiast o proces dekoncentrowania, a więc przesuwania kompetencji z jednego organu do drugiego ${ }^{14}$. Przenoszenie kompetencji na organy niższego stopnia lub usytuowane na tym samym poziomie, dokonywane jest na mocy aktów normatywnych, przy zachowaniu ich hierarchiczności.

W ten sposób można wyróżnić dekoncentrację pionową, zwaną terytorialną, oraz dekoncentrację poziomą, zwaną resortową. Wyodrębnia się także dekoncentrację skośną, która występuje wtedy, kiedy kom-

11 J. Sobczak, Decentralizacja administracji publicznej a zadania samorzadu terytorialnego [w:] Ustrój..., red. A. Lutrzykowski, s. 34.

12 J. Sobczak, Decentralizacja... [w:] Ustrój..., red. A. Lutrzykowski, s. 34.

13 J. Niczyporuk, Dekoncentracja..., s. 48.

14 S. Fundowicz, Decentralizacja administracji publicznej w Polsce, Lublin 2005, s. 27. 
petencje organów jednego resortu przekładane są na organy niższego stopnia organizacyjnego w drugim resorcie ${ }^{15}$. Pamiętać należy, że dekoncentracja dokonywana jest tylko w przypadkach przewidzianych przez prawo, czyli organy administracji nie mogą swobodnie przekazywać swoich kompetencji.

W dekoncentracji scentralizowanej administracji publicznej należy szczególne znaczenie prawne przypisać wykorzystaniu form zależności służbowej ${ }^{16}$. Przenoszeniu uprawnień towarzyszy zachowanie nadrzędności hierarchicznej organów zwierzchnich w zakresie realizacji przekazanych kompetencji ${ }^{17}$. W systemie scentralizowanym występuje organizacyjne podporządkowanie o charakterze hierarchicznym, którego cechą wyróżniającą jest brak samodzielności prawnej podmiotu (organu, kierownika jednostki administrującej) niższego stopnia wobec organu wyższego stopnia ${ }^{18}$. Jeśli zaś w katalogu środków oddziaływania kierujący organ posiada uprawnienie do wydawania wiążących poleceń i wytycznych, a przy tym może jeszcze decydować o obsadzie personalnej organu kierowanego, to układ wzajemnych relacji zachodzących między organami przybiera postać stosunku podległości bezpośredniej oraz hierarchicznego podporządkowania ${ }^{19}$. M. Chmaj uważa, że „hierarchiczne podporządkowanie dotyczy nie tylko stosunków pomiędzy organami wyższego i niższego stopnia, lecz również pomiędzy urzędnikami, a ich przełożonymi. Tego typu zależności określa się podporządkowaniem służbowym"20. Hierarchiczne podporządkowanie w układzie scentralizowanym staje się cechą szczególną tzw. formacji mundurowych, w których Policja zajmuje kluczową pozycję.

W wymiarze terytorialnym Policja obejmuje zintegrowaną strukturę organizacyjną funkcjonującą na poziomie centralnym i tereno-

${ }^{15}$ S. Fundowicz, Decentralizacja..., s. 27.

${ }^{16}$ J. Niczyporuk, Dekoncentracja..., s. 90.

${ }_{17}$ Administracja..., red. M. Karpiuk, J. Kowalski, s. 22.

${ }_{18}$ Nadzór administracyjny. Od prewencji do weryfikacji, red. C. Kociński, Wroclaw 2006, s. 41.

19 Administracja..., red. M. Karpiuk, J. Kowalski, s. 148.

${ }^{20}$ Prawo..., red. M. Chmaj, s. 91. 
wym, z zachowaniem zasady hierarchicznego podporządkowania ${ }^{21}$. Organizacja Policji stanowi strukturę scentralizowaną o silnym hierarchicznym podporządkowaniu, wyrażającym się w zależności osobowej i służbowej ${ }^{22}$. Zależność służbowa polega na tym, że podporządkowany podmiot organizacyjny (organ) nie posiada wobec organu nadrzędnego (nadzorczego) w zakresie swego działania prawnie określonej samodzielności ${ }^{23}$. Zależność osobowa polega natomiast na podporządkowaniu osoby sprawującej urząd jako pracownika w zakresie jego sytuacji pracowniczej, w pełnym zakresie jego przełożonemu ${ }^{24}$. Hierarchiczne podporządkowanie oznacza, iż jednostki niższego rzędu uzależnione są od organów wyższego stopnia i brak im samodzielności. Hierarchiczność wyrażająca się w zależności służbowej - polega również na tym, że brak jest prawnego ograniczenia możliwości wydawania poleceń służbowych przez organ wyższy niższym; oznacza to, iż organ niższego rzędu w każdej sprawie może otrzymać polecenie określonego zachowania się i będzie to prawnie dopuszczalne; zależności osobowej - przejawiającej się w kompetencji organu wyższego stopnia do obsadzania stanowisk w organach niższego stopnia, przy czym mogą to być zarówno jednostki bezpośrednio i pośrednio niższego stopnia; może w tym zakresie dokonywać przyjmowania i zwalniania, awansowania i nagradzania pracowników oraz pociągania ich do odpowiedzialności i wymierzania $\operatorname{kar}^{25}$. $\mathrm{Na}$ czele organizacji zhierarchizowanych stoją organy administracji spełniające określone funkcje zarówno dla danej organizacji, jak w samym systemie organów administracji rządowej i przybierające określoną postać prawną.

Dokonując doktrynalnych porównań, można odnieść wrażenie, że sposób zorganizowania Policji ulega ciągłej ewolucji od próby zorganizowania na zasadzie decentralizacji do stanu jej scentralizowania. Wydaje się, że zarówno teza o centralizacji, jak i teza o decen-

${ }^{21}$ A. Letkiewicz, T. Szankin, Organizacja i zarządzanie. Kompetencje menedżerskie w Policji, Szczytno 2013, s. 218.

${ }^{22}$ Materialne prawo administracyjne, red. M. Miemiec, Warszawa 2013, s. 161.

${ }^{23}$ Nadzór..., red. C. Kociński, s. 41.

${ }^{24}$ Nadzór..., red. C. Kociński, s. 42.

${ }^{25}$ Prawo..., red. M. Chmaj, s. 90-91. 
tralizacji Policji wzajemnie się nie wykluczają. Problemem jest tylko szukanie właściwych proporcji w stosowaniu tych dwóch zasad organizacyjno-ustrojowych ${ }^{26}$. Ponad dwudziestoletnie doświadczenia Policji w zakresie jej organizacji, finansowania oraz realizacji podstawowych zadań pozwalają na postawienie tezy, że funkcjonuje ona w systemie „mieszanym”, gdzie oprócz obszarów postępującej decentralizacji znajduje się ona w systemie scentralizowanym $\mathrm{z}$ dekoncentracją kompetencji. Generalnie należy przyjąć, że Policja ma charakter scentralizowany i jest zorganizowana na zasadzie hierarchicznego podporządkowania ${ }^{27}$.

Zasada hierarchicznego podporządkowania jest cechą w szczególności charakteryzującą formacje mundurowe. Jej przejawem jest ścisła zależność organów niższego stopnia od odpowiednich organów nadrzędnych ${ }^{28}$. Oznaką hierarchicznego podporządkowania są przepisy wydanego na podstawie ustawy o Policji zarządzenia nr 30 Komendanta Głównego Policji z 16.12.2013 r. w sprawie funkcjonowania organizacji hierarchicznej w Policji ${ }^{29}$. Komendant Główny Policji, wydając cytowany akt wewnętrznego kierownictwa, określił, że „organizacja hierarchiczna” to stan wewnętrznego zorganizowania Policji w systemie podporządkowania, a także wzajemnych uprawnień i obowiązków organów Policji oraz policjantów i pracowników Policji. Samo zaś funkcjonowanie organizacji hierarchicznej w Policji to nic innego jak przestrzeganie właściwości terytorialnej i rzeczowej organów Policji, przestrzeganie zasad podejmowania decyzji i wydawania poleceń określonych przepisami prawa policyjnego, które są niezbędne do realizacji zadań tej formacji oraz stosowanie odpowiednich sposobów i metod wykonywania tych zadań, a także zasad postępowania wynikających ze starszeństwa stopni policyjnych. Przywilejem

${ }^{26}$ S. Pieprzny, Między centralizacją a decentralizacją Policji, „Przegląd Policyjny” 2011/2, s. 19.

${ }^{27}$ J. Bodio, G. Borkowski, T. Demendecki, Ustrój organów ochrony prawnej. Czesść szczegółowa, Warszawa 2011, s. 255.

${ }_{28}$ M.K. Jurgilewicz, Podstawy systemu organizacyjnego Policji [w:] Państwo administracja Policja. Ksiega pamiątkowa dedykowana Profesorowi Kazimierzowi Rajchelowi, red. A. Letkiewicz, A. Misiuk, Szczytno 2012, s. 235.

${ }^{29}$ Dz.Urz. KGP poz. 99 ze zm. 
funkcjonariuszy posiadających wyższy stopień policyjny jest możliwość wydawania poleceń policjantom o niższym stopniu dotyczących właściwego wykonywania czynności służbowych czy też zachowania, z wyłączeniem przypadku, gdy osoba $\mathrm{z}$ niższym stopniem sprawuje funkcję organu lub jest przełożonym policjanta posiadającego wyższy stopień. Organizacja hierarchiczna w Policji ma pewne cele, do których zaliczyć można:

1) jednolitość, sprawność, szybkość, ekonomiczność i efektywność czynności służbowych;

2) zdolność struktur organizacyjnych Policji do działań uporządkowanych;

3) ustalenia odpowiedzialności indywidualnej w przypadku naruszenia prawa, bezczynności pomimo obowiązku działania albo wykonywania zadań służbowych w sposób profesjonalnie wadliwy ${ }^{30}$.

Podporządkowanie hierarchiczne to ustopniowany według określonych zasad układ stanowisk lub władz urzędniczych; zawiera więzi organizacyjne występujące pomiędzy organami lub ich pracownikami obejmujące możliwość wydawania dyspozycji ogólnych, indywidualnych poleceń i instrukcji szczegółowych ${ }^{31}$. Postawione cele, jak też sposób ich realizacji, świadczą o układzie i powiązaniach wśród organów Policji oraz sformalizowanych relacjach pomiędzy funkcjonariuszami na określonych szczeblach zorganizowania przy uwzględnieniu starszeństwa stopni policyjnych. Skutkuje to funkcjonowaniem zasad związanych ściśle z dyscypliną służbową, mającą sprzyjać sprawności realizacji ustawowych zadań Policji oraz sprawności działania tej instytucji ${ }^{32}$.

Analizując aspekty prawne funkcjonowania organów Policji, podkreślić trzeba fakt, że pomimo ich monokratycznego charakteru, a także niekwestionowanej pozycji w zakresie zarządzania, przepisy

${ }^{30} \S 3$ zarządzenia nr 30 Komendanta Głównego Policji z 16.12.2013 r. w sprawie funkcjonowania organizacji hierarchicznej w Policji.

${ }^{31}$ Leksykon policyjny, red. W. Pływaczewski, G. Kędzierska, Szczytno 2001, s. 220.

32 W.S. Majchrowicz, Zlecanie zadań stużbowych w Policji. Zarys problematyki, Słupsk 2013, s. 13. 
prawa w znacznej mierze kształtują zadania całej Policji lub też poszczególnych jednostek organizacyjnych. Przykładem jest ustawa z 6.04.1990 r. o Policji (Dz.U. z 2017 r. poz. 2067 ze zm.) określająca zadania całej formacji oraz zarządzenie nr 1041 Komendanta Głównego Policji z 28.09.2007 r. w sprawie szczegółowych zasad organizacji i zakresu działania komend, komisariatów i innych jednostek organizacyjnych Policji ${ }^{33}$. W cytowanym zarządzeniu Komendant Główny Policji określił między innymi zadania Komendy Głównej Policji, komendy wojewódzkiej Policji, komendy powiatowej Policji i komisariatu (specjalistycznego) Policji. Komendant Główny Policji, korzystając ze swoich uprawnień, przekazał do realizacji zadania na niższe szczeble, przywiązując je co do zasady do organów właściwych zgodnie z podziałem administracyjnym kraju (z wyjątkiem komendantów komisariatów Policji) ${ }^{34}$.

Komendant Główny Policji zajmuje najwyższe miejsce w zhierarchizowanej Policji, czego potwierdzeniem są przepisy ustawy o Policji. Władztwo kierownicze, które posiada Komendant Główny Policji, daje mu szerokie uprawnienia wobec wszystkich policyjnych organów terenowych Policji oraz policjantów. W ramach tego władztwa może stosować wszelkie środki oddziaływania na podległe kadry, z wyjątkiem tylko tych, które są zakazane przez prawo ${ }^{35}$. Podobne uprawnienia mają organy niższego szczebla (organy terenowe), które również w ramach posiadanych uprawnień - władztwa - oddziałują na podporządkowane sobie organy i funkcjonariuszy Policji. Komendant wojewódzki Policji oraz komendant powiatowy (miejski) Policji są przełożonymi policjantów na terenie swojego działania. Podejmują oni prawem przewidziane działania, ale też zobowiązani są do rozpatrywania i załatwiania spraw nie tylko podległych organów, ale również wszystkich funkcjonariuszy Policji na terenie swojego działania.

${ }^{33}$ Dz.Urz. KGP z 2013 r. poz. 50 ze zm.

${ }^{34}$ B. Jaworski, Pozycja prawna Komendanta Głównego Policji jako centralnego organu administracji rządowej, Rzeszów 2016, s. 66.

35 S. Pieprzny, Między..., s.16. 
Przy rozpatrywaniu spraw policjantów obowiązuje droga służbowa, co również świadczy o hierarchicznym podporządkowaniu w szeregach Policji. Definicja „drogi służbowej” zawarta została w rozporządzeniu Ministra Spraw Wewnętrznych z 14.05.2013 r. w sprawie szczegółowych praw i obowiązków oraz przebiegu służby policjantów ${ }^{36}$. Droga służbowa oznacza tryb zwracania się policjanta w sprawie osobowej lub innej sprawie wynikającej ze stosunku służbowego do przełożonego uprawnionego do jej załatwienia za pośrednictwem bezpośredniego przełożonego. W celu rozpatrzenia służbowych lub osobistych spraw policjantów wyżsi przełożeni przyjmują podwładnych indywidualnie we wskazanym czasie. W sprawach pilnych policjant powinien mieć możliwość przedstawienia swojej sprawy niezwłocznie ${ }^{37}$. W sposób szczególny uregulowana została możliwość zwracania się do Komendanta Głównego Policji, co jest wyrazem jego pozycji oraz uprawnień mających swoje odniesienie w zasadzie centralizacji. Do bezpośredniego zwracania się w sprawach służbowych do Komendanta Głównego Policji i jego zastępców są uprawnieni wyłącznie: Komendant Stołeczny Policji, komendanci wojewódzcy Policji, Komendant - rektor Wyższej Szkoły Policji w Szczytnie, komendanci szkół policyjnych, dyrektorzy biur lub równorzędnych komórek organizacyjnych Komendy Głównej Policji, dyrektor instytutu badawczego oraz osoby upoważnione do tego przez Komendanta Głównego Policji.

Konsekwencją hierarchicznego podporządkowania Policji jest również szczególny charakter stosunku służbowego łączącego policjanta $\mathrm{z}$ jego formacją ${ }^{38}$. Stosunek ten powstaje $\mathrm{w}$ wyniku mianowania, a w przypadku osób pełniących funkcję organu Policji jest to powołanie. Przejawem podległości służbowej są kompetencje do powoływania i odwoływania organów podległych lub też do wnioskowania o powołanie (odwołanie). Komendant Główny Policji występuje do ministra właściwego do spraw wewnętrznych z wnioskiem o powo-

36 Dz.U. poz. 644 ze zm.

${ }^{37}$ Pkt 10 zarządzenia nr 7 Komendanta Głównego Policji z 1.03.2013 r. w sprawie regulaminu musztry w Policji (Dz.Urz. KGP poz. 18).

${ }_{38}$ Z. Nowakowski, M. Pomykała, J. Rajchel, K. Rajchel, H. Tokarski, Administracja bezpieczeństwa i porządku publicznego ze szczególnym uwzględnieniem aspektów prawno-organizacyjnych Policji, Warszawa 2009, s. 164. 
łanie komendanta wojewódzkiego Policji, zaś samodzielnie powołuje I zastępcę i zastępców komendanta wojewódzkiego Policji (I zastępcę i zastępców komendanta Stołecznego Policji).

Kluczowym przepisem świadczącym o hierarchiczności są unormowania zawarte w art. 32 ustawy o Policji, w którym określono, że do mianowania policjanta na stanowiska służbowe, przenoszenia oraz zwalniania z tych stanowisk właściwi są przełożeni: Komendant Główny Policji, Komendant CBŚP, Komendant BSWP, komendanci wojewódzcy i powiatowi (miejscy) Policji oraz komendanci szkół policyjnych. Przepis ten nieprzypadkowo jako pierwszego wymienia Komendanta Głównego Policji. Potwierdza on jego dominującą pozycję w hierarchii policyjnej. Podobnie wygląda sytuacja z możliwością przeniesienia czy też delegowania policjantów, w tym zakresie kompetencje Komendanta Głównego Policji obejmują teren całego państwa. Ponadto może on delegować policjanta (za jego zgodą) do pełnienia zadań służbowych poza Policją w kraju lub za granicą.

Uprawnienia kierownicze wobec podległych policjantów są wyznacznikiem miejsca w hierarchii Komendanta Głównego Policji. Jednym z tych elementów są uprawnienia do wyróżniania ${ }^{39} \mathrm{i}$ nagradzania policjantów, wyrażone w art. 87 i 110a ustawy o Policji. Nagrody motywacyjne przyznają przełożeni $z$ własnej inicjatywy lub na wniosek innego przełożonego policjanta $\mathrm{w}$ oparciu o udokumentowane $\mathrm{w}$ formie pisemnej okoliczności ${ }^{40}$, z zastrzeżeniem, że Komendant Główny Policji przyznaje

${ }^{39}$ W myśl $₫ 1$ ust. 1 rozporządzenia Ministra Spraw Wewnętrznych i Administracji z 18.11.2003 r. w sprawie szczegółowego trybu postępowania przy udzielaniu wyróżnień policjantom (Dz.U. poz. 1932 ze zm.) „Wyróżnień, o których mowa w art. 87 ust. 1 pkt 1 i 2 ustawy z dnia 6 kwietnia 1990 r. o Policji, zwanej dalej «ustawą», udzielają policjantom Komendant Główny Policji, Komendant Centralnego Biura Śledczego Policji, Komendant Biura Spraw Wewnętrznych Policji, komendanci wojewódzcy (Komendant Stołeczny) Policji, komendanci powiatowi (miejscy, rejonowi) Policji oraz komendanci szkół policyjnych. 2. Wyróżnienia, o których mowa w art. 87 ust. 1 pkt 4 ustawy, udzielają policjantom Komendant Główny Policji, Komendant Centralnego Biura Śledczego Policji, Komendant Biura Spraw Wewnętrznych Policji, komendanci wojewódzcy (Komendant Stołeczny) Policji, z wyjątkiem przypadku, o którym mowa w art. 48 ust. 3 ustawy".

$40 \$ 2$ ust. 1 rozporządzenia Ministra Spraw Wewnętrznych z 25.09.2014 r. w sprawie nagród i zapomóg dla policjantów oraz tworzenia funduszu nagród i zapomóg dla policjantów (Dz.U. poz. 1314 ze zm.). 
nagrody motywacyjne między innymi Komendantowi Centralnego Biura Śledczego Policji i jego zastępcom, komendantom wojewódzkim (Stołecznemu) Policji i ich zastępcom. Komendant Główny Policji oraz komendanci wojewódzcy (Stołeczny) Policji posiadają prawo do nagradzania wszystkich policjantów (z wyłączeniem swoich zastępców), każdy na terenie swojego działania. Zauważyć należy, że pomimo przekazania terenowym organom Policji kompetencji do nagradzania Komendant Główny Policji zachował prawo do wyróżniania i nagradzania wszystkich policjantów, niezależnie od tego, gdzie pełnią służbę.

Podobnie sytuacja wygląda w przypadku odpowiedzialności dyscyplinarnej policjantów, gdzie za przełożonego dyscyplinarnego uważa się przełożonego, o którym mowa w art. 32 ust. 1 ustawy o Policji. Wyższymi przełożonymi dyscyplinarnymi w postępowaniu dyscyplinarnym są:

1) komendant wojewódzki Policji - w stosunku do komendanta powiatowego (miejskiego) Policji;

2) Komendant Stołeczny Policji - w stosunku do komendanta powiatowego (miejskiego) i rejonowego Policji;

3) Komendant Główny Policji - w stosunku do Komendanta Centralnego Biura Śledczego Policji, komendanta wojewódzkiego Policji, Komendanta Stołecznego Policji, komendanta szkoły policyjnej i dowódcy kontyngentu policyjnego.

W tym przypadku dostrzegalna jest czołowa rola Komendanta Głównego Policji, czego przejawem jest także brak możliwości odwołania się od orzeczenia czy postanowienia, które zostało wydane przez niego, jako organ pierwszej instancji, przysługuje tutaj jedynie wniosek o ponowne rozpatrzenie spraw.

Jeżeli chodzi o postępowanie administracyjne w sprawach związanych z wykonywaniem zadań i kompetencji Policji domniemanie właściwości przypisane zostało komendantowi powiatowemu (miejskiemu) Policji, a na obszarze miasta stołecznego Warszawy - komendantowi rejonowemu Policji. Organami wyższego stopnia są odpowiednio komendant wojewódzki Policji, Komendant Stołeczny Policji oraz Komendant Główny Policji. 
Działając na podstawie ogólnej normy kompetencyjnej zawartej w art. 5 ust. 1 ustawy o Policji, Komendant Główny Policji jest odpowiedzialny za realizację zadań z zakresu ochrony bezpieczeństwa ludzi oraz utrzymania bezpieczeństwa i porządku publicznego w całym państwie. Do realizacji tego ustawowego celu przeznaczeni zostali policjanci, których przełożonym jest właśnie Komendant Główny Policji, dlatego jego ustawowym uprawnieniem jest możliwość wydawania wiążących poleceń oraz kontroli realizacji zadań i nadzoru. Instytucją prawną realizacji stosunku nadrzędności jest nadzór, który należy traktować jako uprawnienie właściwego nadrzędnie czy to organizacyjnie, czy funkcjonalnie podmiotu do władczego wkraczania w działalność podmiotu nadzorowanego. Podstawowym zadaniem nadzoru jest właściwa realizacja prawnie określonych zadań i celów podmiotu administracji ${ }^{41}$. System nadzoru i kontroli jest gwarantem przestrzegania zasad oraz potwierdza, że komendanci Policji sprawujący funkcję organów realizują swoje zadania według zasad organizacji hierarchicznej. Trzeba stwierdzić, że usytuowanie tych podmiotów, czyli organów Policji względem siebie, a także policjantów wobec organów Policji i wobec siebie - w układzie centralizacji - nie oznacza zarazem nieposiadania pewnego zakresu własnych zadań i kompetencji przez organy Policji oraz własnych uprawnień i obowiązków przez policjantów ${ }^{42}$.

Komendant Główny Policji posiada również liczne kompetencje prawotwórcze i organizacyjne ${ }^{43}$, dzięki którym dopełnia swoją rolę cen-

${ }^{41}$ M. Róg, Problematyka nadzoru i koordynacji $w$ procesach legislacyjnych $w$ organach Policji [w:] Proces dostosowania polskiego prawa policyjnego i prawa stosowanego przez Policje do prawa europejskiego, red. K. Choiński, I. Nowicka, Szczytno 2009, s. 76-77.

42 I. Niżnik-Dobosz, Podmiotowość administracyjnoprawna Policji na gruncie ustawy z 6 kwietnia 1990 r. o Policji [w:] 95 lat stużb policyjnych w Polsce, red. E. Ura, S. Pieprzny, Rzeszów 2015, s. 115.

${ }^{43}$ Zgodnie z art. 7 ust. 1 ustawy o Policji Komendant Główny Policji określa: szczegółowe zasady organizacji i zakres działania komend, komisariatów i innych jednostek organizacyjnych Policji; metody i formy wykonywania zadań przez poszczególne służby policyjne w zakresie nieobjętym innymi przepisami wydanymi na podstawie ustawy; programy szkoleń zawodowych policjantów; zakres oraz szczegółowe warunki, tryb przeprowadzania oraz zasady oceniania testu sprawności fizycznej policjantów; szczegółowe zasady szkolenia zwierząt wykorzystywanych do realizacji zadań Policji, 
tralnego organu administracji rządowej. Uprawnienia Komendanta Głównego Policji związane z centralizacją i dekoncentracją Policji dostrzegalne są na wielu płaszczyznach jego działalności, a przykłady można by mnożyć i powielać. Stwierdzić trzeba, że kluczem podejmowanej działalności jest miejsce Komendanta Głównego Policji w systemie zhierarchizowanych organów Policji.

Dostrzegalnym zjawiskiem jest skupienie szeregu kompetencji w gestii Komendanta Głównego Policji i jednoczesne ograniczenie samodzielności terenowych organów Policji, co również stanowi o centralizacji Policji. Ten centralny organ korzysta $z$ wielu narzędzi, takich jak wydawanie poleceń, instrukcji, wytycznych i aktów wewnętrznego kierownictwa, w celu regulacji funkcjonowania organów niższego szczebla, jak również wszystkich funkcjonariuszy Policji. Podobne uprawnienia mają organy terenowe Policji w stosunku do podporządkowanych sobie struktur, co z kolei jest przejawem dekoncentracji uprawnień. Rozproszenie uprawnień ma na celu usprawnienie funkcjonowania Policji na wszystkich szczeblach jej organizacji. Szczególnie dostrzegalny przejaw dekoncentracji ma miejsce w aspekcie kształtowania struktur organizacyjnych. Komendant Główny Policji w cytowanym zarządzeniu nr 1041 scedował możliwość organizacji jednostek i komórek organizacyjnych na stopniu województwa i powiatu, na komendantów wojewódzkich oraz powiatowych (miejskich) Policji ${ }^{44}$.

a także normy ich wyżywienia; zasady etyki zawodowej policjantów, po zasięgnięciu opinii związku zawodowego policjantów; organizację, rzeczowy i miejscowy zakres działania oraz zasady współdziałania CBŚP z innymi jednostkami organizacyjnymi Policji.

${ }^{44} \$ 9$ Komendant wojewódzki Policji podejmuje decyzje w sprawach: 1) tworzenia, likwidacji lub przekształcania komórek w komendzie wojewódzkiej Policji; 2) tworzenia lub likwidacji komisariatu specjalistycznego Policji w porozumieniu z Komendantem Głównym Policji oraz przekształcania jego struktury organizacyjnej i etatowej; 3) ustalania struktury organizacyjnej i etatowej ośrodka szkolenia Policji, z zachowaniem liczby etatów policyjnych przyznanych przez Komendanta Głównego Policji.

$\$ 10$ Komendant powiatowy Policji podejmuje decyzje w sprawach: 1) tworzenia, likwidacji lub przekształcania komórek w komendzie powiatowej Policji; 2) tworzenia lub likwidacji komisariatu Policji; 3) tworzenia, likwidacji lub przekształcania komórek w komisariacie Policji. 
Przedstawione przykłady odnoszące się do systemu zhierarchizowanych organów Policji jednocześnie potwierdzają założenie o ich centralistycznym podporządkowaniu. Centralistyczne podporządkowanie organów Policji jest jednym z głównych fundamentów funkcjonującego systemu, w którym w zależności od szczebla usytuowania różni się ich rola, a uprawnienia podlegają reglamentacji. Stosowanie zaś elementów dekoncentracji ułatwia administrowanie tej mało elastycznej formacji, jaką jest Policja, oraz usprawnia jej działanie.

\section{Bibliografia:}

Administracja publiczna i prawo administracyjne w zarysie, red. M. Karpiuk, J. Kowalski, Warszawa-Poznań 2013

Bodio J., Borkowski G., Demendecki T., Ustrój organów ochrony prawnej. Część szczegółowa, Warszawa 2011

Fundowicz S., Decentralizacja administracji publicznej w Polsce, Lublin 2005 Izdebski H., Ustrój terytorialny Rzeczypospolitej Polskiej i zasada decentralizacji [w:] Ustrój terytorialny państwa a decentralizacja systemu władzy publicznej, red. A. Lutrzykowski, Toruń 2012

Jaworski B., Pozycja prawna Komendanta Głównego Policji jako centralnego organu administracji rządowej, Rzeszów 2016

Jurgilewicz M.K., Podstawy systemu organizacyjnego Policji [w:] Państwo administracja Policja. Księga pamiątkowa dedykowana Profesorowi Kazimierzowi Rajchelowi, red. A. Letkiewicz, A. Misiuk, Szczytno 2012

Leksykon policyjny, red. W. Pływaczewski, G. Kędzierska, Szczytno 2001

Letkiewicz A., Szankin T., Organizacja i zarządzanie. Kompetencje menedżerskie w Policji, Szczytno 2013

Majchrowicz W.S., Zlecanie zadań służbowych w Policji. Zarys problematyki, Słupsk 2013

Materialne prawo administracyjne, red. M. Miemiec, Warszawa 2013

Nadzór administracyjny. Od prewencji do weryfikacji, red. C. Kociński, Wroclaw 2006

Niczyporuk J., Dekoncentracja administracji publicznej, Lublin 2006

Niżnik-Dobosz I., Podmiotowość administracyjnoprawna Policji na gruncie ustawy z 6 kwietnia 1990 r. o Policji [w:] 95 lat służb policyjnych $w$ Polsce, red. E. Ura, S. Pieprzny, Rzeszów 2015 
Nowakowski Z., Pomykała M., Rajchel J., Rajchel K., Tokarski H., Administracja bezpieczeństwa i porządku publicznego ze szczególnym uwzględnieniem aspektów prawno-organizacyjnych Policji, Warszawa 2009

Pakuła A., Centralne organy administracji rządowej - rządzenie czy zarządzanie sprawami publicznymi [w:] Nowe problemy badawcze $w$ teorii prawa administracyjnego, red. J. Boć, A. Chajbowicz, Wrocław 2009

Pieprzny S., Między centralizacją a decentralizacją Policji, „Przegląd Policyjny” $2011 / 2$

Prawo administracyjne. Część ogólna, red. M. Chmaj, Warszawa 2007

Prawo administracyjne, red. M. Wierzbowski, Warszawa 2011

Róg M., Problematyka nadzoru i koordynacji w procesach legislacyjnych $w$ organach Policji [w:] Proces dostosowania polskiego prawa policyjnego i prawa stosowanego przez Policję do prawa europejskiego, red. K. Choiński, I. Nowicka, Szczytno 2009

Sobczak J., Decentralizacja administracji publicznej a zadania samorządu terytorialnego [w:] Ustrój terytorialny państwa a decentralizacja systemu władzy publicznej, red. A. Lutrzykowski, Toruń 2012

Sprengel B., Decentralizacja policji w Polsce od okresu międzywojennego do III Rzeczypospolitej [w:] Ustrój terytorialny państwa a decentralizacja systemu władzy publicznej, red. A. Lutrzykowski, Toruń 2012

Wrzosek S., Kompendium wiedzy administratywisty, Lublin 2008

Zimmermann J., Prawo administracyjne, Warszawa 2012 